\title{
Unpaid wages: the experiences of Irish Magdalene Laundries and Indigenous Australians
}

\author{
James Gallen* and Kate Gleeson **
}

\begin{abstract}
This paper will evaluate the obstacles faced by victim-survivors of historical abuse, particularly victimsurvivors of forced labour in Magdalene Laundries in Ireland and the stolen wages of Australian Aborigines and Torres Strait Islanders, in a post-colonial transitional justice framework. First, the paper identifies challenges in contextualising comparative interdisciplinary historical research in terms of transitional justice. Second, the paper considers the economic contribution of unpaid labour in the Australian and Irish contexts and, third, goes on to examine the historical denial of rights and redress in both settings. The paper then evaluates the different challenges in responding to legacies of historical abuse, especially unpaid wages in both states. A final section concludes with the argument that redress provided in both instances represents a form of paternalism perpetuating the colonial approach to governance, rather than the provision of the legal rights of citizens, and that this paternalism has specific implications for women who continue to be marginalised by contemporary regimes.
\end{abstract}

\section{Introduction}

Despite the central prohibition on slavery in international human rights law, some modern, consolidated democracies persistently resist redressing past exploitative labour practices through a narrow interpretation of historical slavery. This paper compares the obstacles faced by victimsurvivors of forced labour in Magdalene Laundries in Ireland and the 'stolen wages' of Aboriginal and Torres Strait Islander peoples in Australia. ${ }^{\mathrm{I}}$ Despite state-led redress mechanisms, there remains great dissatisfaction about the nature and extent of legal and moral responsibility accepted by state and Church institutions in each country. Both contexts concern serious human rights abuses, both have a significant gendered dimension to the harm experienced and both reflect the difficulties of achieving meaningful legal accountability and responsibility for historical forms of injustice, despite ongoing consequences for victim-survivors.

In Australia, very many Indigenous workers either worked for no remuneration under discriminatory laws and awards or they had their wages stolen under paternalistic wage-garnering regimes, from the time of conquest until at least the I980s (Standing Committee on Legal and Constitutional Affairs, 2006). While the magnitude of this underpayment and theft is impossible to establish, it is estimated that, in the state of Queensland alone, at least A\$500 million is owed in current prices (Kidd, 2006, p. 9).

* Lecturer, School of Law and Government, Dublin City University. E-mail: james.gallen@dcu.ie

** Senior Lecturer, Macquarie Law School, based on the land of the Darug nation.

E-mail: kate.gleeson@mq.edu.au.

I Note on terminology: this paper uses the term 'victim-survivor' to enable individuals who have experienced serious harm to self-identify in their own manner. See Rock (2002, p. I4). 'Stolen wages' is an Australian idiom purposefully associated with the Stolen Generations of Indigenous children to represent the multi-faceted injustices of colonisation. In the relevant Australian legislation and government policies, 'Aboriginal' refers to Aborigines. 'Indigenous' refers to Aboriginal and Torres Strait Islander people, to whom some legislation also pertained. 
In Ireland, Magdalene Laundries were originally excluded from state-led national inquiries into child sexual abuse commenced in the late twentieth century (Ryan, 2009). At an absolute minimum, approximately I4,607 women are known to have been detained in a Magdalene Laundry from the foundation of the Irish state in 1922 until I996, though victim-survivor groups suggest these figures are underestimated (JFM, 2013). Women detained in laundries were obliged to engage in forced and unpaid labour, for which there remains no legal admission of state or Church responsibility.

This paper applies an interdisciplinary account of transitional justice as an evaluative lens to the question of unpaid wages in Australia and Ireland. There is growing recognition of the applicability of transitional justice theories to consolidated democracies (Winter, 20I4) and challenges to the idea that transitional justice offers a self-contained or distinctive conception of justice (Nagy, 20I3). Patricia Lundy and Mark McGovern argue that the paradigm of transitional justice ignores the problem that human rights abuses may continue to take place in circumstances where, in theory at least, the norms of liberal democratic accountability prevail' (2008, p. 273). This paper positions itself as part of this expansion of transitional justice to address structural harms beyond postconflict contexts to consider its application in post-colonial settings, and focuses on the question of unpaid wages as part of a larger pattern of abuse. This approach challenges the notion of a narrow temporal scope to 'transition' in transitional justice discourse and encourages consideration of enduring structural arrangements and consequent harms in post-colonial contexts (Balint et al., 20I4, pp. 200-20I). In addition, the examination of historical abuse in this paper illustrates the impact of different forms of government in influencing the pace and nature of redressing past wrongs and assesses whether a human rights discourse offers any advantage to vulnerable groups.

Indeed, there is a growing recognition of the value in applying transitional justice as an evaluative framework to inquiries into historical abuse. Joanna Sköld employs transitional justice to consider a range of inquiries across common law jurisdictions, Nordic states and across Europe address institutional child abuse (Sköld, 2015; 20I6). McAlinden and Browyn Naylor have considered the use of restorative and transitional justice theories as a means for evaluating and developing the role of public inquires, suggesting a restorative justice model may enhance offender accountability and strengthen the voice given to victims (McAlinden and Naylor, 20I6). James Gallen has considered the role of transitional justice as an evaluative framework to assess the role of relevant states and the Roman Catholic Church, the Holy (see, regarding the issue of child sexual abuse, Gallen, 20I6). On Gallen's account, a transitional justice approach responds to 'need for a cross-cutting discourse to compare and examine the impact of institutional designs and practices in responding to the scale and pattern of child sexual abuse in the Catholic Church' (Gallen, 20I6, p. 349). Within the Irish context, the use of transitional justice as a policy mechanism for addressing historical institutional abuse more broadly has received tentative political support, with references in Irish parliament to a transitional justice approach to the related set of institutions, Mother and Baby Homes, designed to house single pregnant women and new mothers (Zappone, 2017). This paper thus sits squarely within an emergent trend in transitional justice discourse and practice, and makes a novel comparison between Ireland and Australia and a novel contribution in examining unpaid wages.

Examining the issue of unpaid wages for individuals and groups subject to other forms of human rights abuses challenges the paradigm of primarily symbolic reparations in transitional justice, designed to acknowledge responsibility for gross violations of human rights (de Greiff, 2006, pp. I-I8). Where contemporary economic information is available, the calculation of unpaid wages is comparatively more straightforward than these symbolic reparations. Beyond the restitution of wages, the potential to provide redress for lost potential earnings and emotional harm returns the reparations discussion to more traditional transitional justice concerns. The 
application of a transitional justice framework to these issues enhances the positioning of these set of historical institutions and practices as part of a larger, global discourse regarding how states address widespread and systemic human rights abuses. This positioning is not merely an academic exercise, but strengthens calls to dispel the suggestion that cases of historical abuse are sui generis and can be addressed in any manner arising from the benevolence of a given state. Instead, framing these contexts as involving questions of transitional justice offers the opportunity to critically apply the depth of international law and policy, comparative national practice and critical scholarship and thinking that this discourse has developed over the last thirty to forty years. In this way, it is hoped that this paper offers an example to enable evaluation, from a transitional justice perspective, of other instances of historical abuse, such as the UK's present Independent Inquiry into Child Sexual Abuse (IICSA, 2017) or the under-explored context of historical detention and alleged abuse in psychiatric institutions (Prior, 2012). Finally, addressing the question of redress for unpaid wages through a feminist lens expands the influence of feminist discourse on transitional justice practice regarding historical abuse in consolidated democracies, to inform a richer conception and practice of a feminist approach to transitional justice.

While the question of Indigenous identity has previously been considered in settler colonial contexts (Jung, 20II; Cunneen, 20I6), a feminist analysis of post-colonial national identity, which informs the experience of women detained in Magdalene Laundries and the labour of Indigenous women in Australia, remains under-explored. Catherine Turner (2017) has recently argued that the feminist critique of transitional justice necessarily remains internal to the accepted dynamic and institutionalisation of transitional justice in its paradigmatic forms: truth commissions trials, reparations, vetting, reconciliation. A gendered approach to addressing unpaid wages in the Australian and Irish contexts challenges the bounded nature of transitional justice, suggesting, with Moyo (20I2), that issues similar to transitional justice arise in historical abuse in postcolonial consolidated democracies. This approach is strengthened by the interdisciplinary analysis of this paper, drawing on a legal, historical and political consideration of the issues of historical abuse in different national political systems and cultures.

In this paper, we examine the nature and pattern of the non-payment of wages and examine how advocates have pursued redress for historical abuse. First, the paper identifies challenges in contextualising comparative historical research. Second, the paper considers the economic contribution of unpaid labour in the Australian and Irish contexts and, third, examines the historical denial of rights and redress in both settings. The paper then evaluates the gendered challenges in responding to a legacy of historical abuse, especially unpaid wages in both states. It concludes with the argument that redress provided in both instances represents a form of paternalism perpetuating the colonial approach to governance, rather than the provision of the legal rights of citizens, and that this paternalism has specific implications for women who continue to be marginalised by contemporary regimes.

\section{Caveats, differences and the potential of comparative historical legal research}

Examining Ireland and Australia regarding historical unpaid wages may not seem an obvious comparison, given the diverse national experiences of colonialism. ${ }^{2}$ This paper offers detailed accounts of both contexts to enable the reader to effectively draw comparison between what may otherwise seem divergent national experiences, but what on reflection demonstrate applications of

2 The case of Australia has typically been described as a form of 'settler colonialism' in which occupation was justified with the legal fiction of Terra Nullius. The case of Ireland has more frequently been considered a form of 'internal colonialism' that situated the Celtic Fringe within the British state. 
post-colonial paternalism with shared and similar features. Drawing from post-colonial legal theory enables us to counter the colonial strategy of 'othering' by enabling the expressed narratives, needs and experiences of the colonised (Kapur, 2002) and those who continued to experience harm in postcolonial nations. Addressing stolen wages in Australia necessarily involves questions of racial discrimination and Indigenous sovereignty including 'loss of cultural rights and fulfillment, and loss of native title rights' (Cunneen, 2003, p. I9). These considerations are not present in the Irish context. The Australian case must also address how the state shifts responsibility due to its federal structure. The historical place of the Catholic Church in Ireland results in a distinctive political and social environment. Regional differences in international legal cultures are also relevant. The struggle to ensure the Irish government address its past legacy of historical abuse has been pursued through international human rights mechanisms, including regional human rights courts, which are not legally or politically applicable to Australia.

However, despite these differences, both examples of colonialism were premised on the exploitative and misguided civilising endeavour of European, Christian paternalism, which ultimately informed and enabled human rights abuses. First, both states inherited paternalistic and discriminatory laws and systems from the British, which, on independence in the twentieth century, each chose to sustain and fortify. ${ }^{3}$ In both countries, these legislative systems reflected a perceived historical need to protect industries and regulate labour as the 'backbone' of each new country's economy from the i86os to I96os.

Second, the abuse had particularly gendered forms. In Ireland, Magdalene Laundries were designed to detain 'fallen women' in response to moral panics regarding prostitution and extramarital sexual behaviour. In Australia, wages practices formed one crucial component of an intricate system of gendered paternalistic 'management' of Indigenous populations aimed at assimilation, including sex-segregated institutions and work environments. However, as we will illustrate, it is male workers who have captured the imaginations of Australia, and therefore, campaigns for justice. In both contexts, the unpaid nature of women's work in these institutional and policy settings occurs against the broader backdrop of women's unpaid care work across family and other social, non-institutional settings.

Finally, advocates in both states are currently seeking to pursue redress for historical abuse. Both states have commissioned government inquiries, but offered only limited ex gratia redress without admission of legal responsibility, coupled with limited states apologies. Both have actively resisted litigation and, some instances, obstructed complainants' claims. The challenges of independently addressing a comparative perspective to historical abuse is exacerbated by the relative lack of public data and records in the two contexts. In Ireland, the records of investigation into the Magdalene Laundries have not been made public. The tireless and extensive work of journalists, academics and the advocacy organisation Justice for Magdalenes should be acknowledged as providing key first-person narratives and testimony regarding the laundries, and in further excavating historical records (JFM, 20I3).

In Australia, state governments have obstructed investigations by withholding what scant records were ever kept. In addressing the past, the harm of detention necessarily dominates modern Magdalene redress campaigns and subsumes the question of unpaid wages. In Australia, abuses associated with institutions, including intergenerational child removal, have been addressed in diverse political and legal fora, with stolen wages emerging as one factor among many (Human

3 Although not a republic, the Commonwealth of Australia was created with a national Constitution in I90I. Dominion status, as an independent sovereign nation, was achieved under the Statute of Westminster I93 I formalising the Balfour Declaration. The Australia Act I986 ended any remaining links between the parliament and judiciary of the UK and the Australian states and territories. The Irish Free state was established by the Anglo-Irish Treaty of 1922 and replaced by Ireland in its present form through the Irish Constitution I937 and formally became a republic under the Republic of Ireland Act I948. 
Rights and Equal Opportunity Commission, I997). Regardless, in both instances, campaigns for redress have produced enough evidence to gauge that significant abuses were committed regarding unpaid labour.

\section{Contribution to the economy: the labour of Indigenous people and women in Magdalene Laundries}

\subsection{Indigenous Australian workers}

The genocidal effects of British settler colonialism in Australia (Moses, 2008) and the focus on land acquisition and transformation have meant that 'prominent narratives of Australian economic development have disregarded Aboriginal participation in the economy' (White, 20II, p. 82). Unpaid labour was, however, central to the frequently violent establishment of Indigenous camps on land occupied by European pastoralists from the time of conquest (Anthony, 2007b, p. 6). By the late nineteenth century, frontier violence was mostly subdued and the colonial relationship was transformed into a form of feudalism granting substantial autonomy to colonisers who, as pastoralists dependent on Indigenous labour, were 'furnished with legitimate rights of public authority' over Indigenous peoples (Anthony, 2003, pp. 283-284). Indigenous camp residents came to exchange pastoral work (men) and domestic labour and sexual relations (women) for 'food clothing and some medical care' (White, 20II, p. 83; McGrath, I987).

While it is important not to obscure the diversity of localised forms of economic 'exclusion, exploitation and domination' (White, 20II, p. 82), contributions made to pastoral economies in the 'top end' of Queensland, the Northern Territory (NT) and Western Australia (WA) made for particularly iconic images of Indigenous stockmen as the backbone of the country's flourishing cattle trade. The lucrative industry was 'largely maintained by the exploitation of cheap [and unpaid] Aboriginal labor' from the mid-nineteenth century until the r96os (Hess, I994, p. 65), when equal-wages campaigns, the expulsion of Indigenous peoples to settlements and advances in agricultural technology coalesced to diminish the supply of cheap Indigenous pastoral labour (Anthony, 2007a, pp. 15-34).

Women, children and the elderly were also integral to the pastoral economy, through the performance of domestic labour and tasks such as 'carrying water from creeks, fencing, yard and road building, digging dams and bores' (Anthony, 2007b, p. 5). Indigenous women and children were the primary source of domestic labour for European farms and households during the late nineteenth and twentieth centuries. Aboriginal girls, oppressed by the 'dual categories of race and gender' (Robinson, 2003, p. I62), were sought-after domestic workers whose 'assimilation' into White households served twin purposes of meeting labour shortages and inculcating the colonial relationship through master and servant-style employment (Robinson, 2014, p. I02). Domestic labour was promoted as a means by which to civilise Indigenous girls, prepare them for their 'lowly' position in society (Robinson, 20I4, p. 98) and 'breed out' Indigeneity. Physical and sexual abuse was commonplace (Human Rights and Equal Opportunity Commission, I997, Chapter Io).

\subsection{The Irish Magdalene Laundries}

Magdalene Laundries were not confined to Ireland, nor the Catholic faith. Their operation pre-dates the foundation of the Irish state in 1922, with the earliest institutions established in the eighteenth century, throughout Europe, North America and Australia (McAleese, 2013, para. 69) They operated in Ireland between 1795 and 1996 (McAleese, 2013, Chapter 3). The laundries were first established by the British, who viewed the role of the Church as contributing to the colonial civilising mission - a view adapted and fortified after independence (Inglis, I998, pp. I47-I48). Since its foundation in I922, the Irish state has estimated a minimum of I4,607 women were confined in ten Magdalene 
institutions operated by four religious orders, with other laundries deemed relevant by victimsurvivor and advocacy groups (McAleese, 20I3, Chapter 8, paras 8-I8). The claimed purpose of the laundries was to house 'fallen women': those involved in prostitution, or unmarried mothers, as 'it was commonly believed that women who had given birth to an illegitimate child would fall into prostitution' (Luddy, 2008). There is little evidence that the institutions had any significant impact on prostitution during the period (Raftery and O'Sullivan, I999, p. I62). Although each laundry had distinctive features, all inmates were required to work and were not paid for any labour. Supervision of women by nuns took the form of daily prayers, penance and physical, verbal and emotional abuse (McAleese, 2013, Chapters I9, 20).

Until recently, Magdalene Laundries were officially regarded by the state as purely private enterprises for which the state has no responsibility (IHRC, 2010, para. 8). No new Magdalene Laundries were established after the foundation of the Irish state in 1922, but rather the laundries were part of 'inherited networks of social control', spanning Magdalene institutions, County Homes, Mother and Baby Homes, Industrial and Reformatory schools, psychiatric hospitals and prisons (O'Sullivan and O'Donnell, 20I2, p. 258). In their view, Ireland during the operation of the laundries 'was an era of low recorded crime, but high perceived deviance in the sense that the contravention of social norms was regularly met with an institutional response' (O'Sullivan and O'Donnell, 20I2, p. 258). During this period, the state provided little or no welfare (Garvin, 2005). The Irish Poor Laws provided for workhouses for the destitute, but otherwise most assistance was framed within a residential institution (Gray, 2009).

Magdalene Laundries are a key element to understanding twentieth-century Ireland's treatment of women and its construction of post-colonial identity. Sheila Killian argues that the social silence surrounding the laundries facilitated their use to avoid accounting for aspects of Irish society that were troubling to the national identity (Killian, 20I5, p. I8). James Smith similarly suggests that the nature of the Magdalene system facilitated the young Irish state in a post-colonial context, helping it to create for itself a separate, Catholic identity, untainted by ideas of prostitution, single motherhood or sexual violence (Smith, 2007). Gender is therefore a defining feature in the history of Magdalene Laundries and, in this context, there are allegations of a variety of forms of gendered abuse (JFM, 20II).

\section{Wage containment: the historical denial of labour rights}

\subsection{Indigenous Australians}

The wages and benefits of Indigenous Australians were stolen, embezzled and simply unpaid through a comprehensive suite of racist protectionist legislation operating at the state, territory and commonwealth levels of government. The most formidable of all, the Protection Acts (the Acts) of the nineteenth and twentieth centuries, were premised on 'an appallingly paternalistic view of Indigenous Australians' (Banks, 2008, p. 55), based on the belief that 'Aborigines were doomed to extinction' (Mitchell and Curthoys, 2010, p. 257). While differing in each jurisdiction, the Acts were commonly used to justify land acquisition, the break-up of families and the 'management' of resources such as wages and other financial benefits. They have been described as representing the 'legislative embodiment of a 6o-year old humanitarian tradition long nourished by differing branches and styles of Evangelical Protestantism' (Boucher, 2015, p. 64). Although this movement had its origins in Britain, the Acts were the product of responsible government formed in the selfgoverning Australian colonies, and reflected the peculiar anxieties of early Australian nationalism. On federation of the country in I90I, the Acts were enhanced, fortified and ruthlessly deployed until the enactment of the Racial Discrimination Act 1975. 
Under the Acts, Indigenous adults and children were subject to the responsibility of a Chief Protector who had 'near-total control' over their lives, including where to live, whether (and whom) to marry and employment relationships (Standing Committee on Legal and Constitutional Affairs, 2006, p. 8). Men, women and children could be directed to live and work on Church and state-run reserves (missions and settlements), requiring substantial unpaid labour such as construction, cooking, farming, gardening, nursing and teaching (Thornton and Luker, 2009, p. 649). Otherwise, they might be instructed to participate in government apprenticeship schemes, or be sent to work for pastoralists and other White households requiring domestic labour, with the terms of their employment and wages negotiated by government protectors (usually police).

The states and territories had slightly different systems of wages control in place. In Queensland, for example, for eighty-five years, the Aboriginals Protection and Restriction of the Sale of Opium Act I897 and its successors made it illegal to employ an Aboriginal person without a government-issued permit (Standing Committee on Legal and Constitutional Affairs, 2006, p. 9). In some sectors, wages were set at a fraction of regular award wages, but in others, such as the pastoral industry, Indigenous workers were excluded from awards altogether (Standing Committee on Legal and Constitutional Affairs, 2006, pp. II-I2). As part of a 'compulsory savings regime', Queensland employers were directed to pay Indigenous workers' wages to the protector, who was entrusted with depositing all or part of the wages into a government bank account in the worker's name (Standing Committee on Legal and Constitutional Affairs, 2006, pp. II-I2). Government benefits, such as child endowment, were also typically garnered (Standing Committee on Legal and Constitutional Affairs, 2006, pp. 29-40). Any remainder was (supposedly) distributed to the employee as 'pocket money' (Standing Committee on Legal and Constitutional Affairs, 2006, pp. II-I2). Indigenous wages were also deposited into welfare funds established for 'the relief of Natives' (Standing Committee on Legal and Constitutional Affairs, 2006, p. I2). In a perverse outcome, this meant that Indigenous Australians involuntarily funded their own 'relief' manifesting as a regime impoverishing and marginalising individuals and families for generations, through policies of wage containment, curtailment of freedom of movement and the removal of children. The proportion of wages garnered increased as regulation was heightened in the twentieth century and regimes similar to Queensland's operated throughout the country. In New South Wales (NSW), along with managing adults' wages, the government made great use of apprenticeship schemes to place children in White households and farms or training schools, where they were 'trained' until deemed old enough to work in indentured labour in private homesteads. Apprenticed children's wages were paid into a trust account, with a small proportion distributed as 'pocket money' (Standing Committee on Legal and Constitutional Affairs, 2006, pp. I4-I6).

It is now apparent that, in all states and territories, few Indigenous workers were ever paid their wages or redeemed their enforced savings. Trust accounts were neither monitored nor 'protected from misappropriation and fraud' (Standing Committee on Legal and Constitutional Affairs, 2006, p. 49). Funds were misappropriated by governments and defrauded by protectors and employers (Standing Committee on Legal and Constitutional Affairs, 2006, p. 49). The majority of Indigenous workers were simply not paid or were very significantly underpaid, for generations. It is impossible to estimate the magnitude of this theft. Rosalind Kidd suggests that up to A $\$ 500$ million in current prices was lost or stolen from Indigenous families in Queensland alone (2006, p. 9).

\subsection{Irish Magdalene Laundries}

Despite diverse institutional practices, residents of Magdalene Laundries commonly worked for long hours in difficult conditions during their detention. Ireland's historical position was that the state had no role in the Magdalene Laundries, the labour undertaken there and no consequent obligation to ensure payment for work done (IHRC, 20I0, para. 8). However, this is difficult to maintain even on a historical account. The 1936 state-commissioned Cussen Report stated: 
'I85. We also consider that these institutions should be remunerated for their work of reformation by the payment of an appropriate grant in respect of girls committed under the arrangements we have recommended, but as the labour of these inmates is of some value, in many cases of commercial value, to the Institutions (e.g. where laundries are conducted) it should be provided that a specified portion of the cash value of the work of the girls in respect of whom grants have been paid should be placed to their credit - in the Post Office Savings Bank or with a philanthropic society or otherwise - and made available for them on leaving.' (Cussen Report, I936, para. 185 , emphasis added)

As early as 1936, the state was on notice that the work of women in Magdalene Laundries was of economic value and should be remunerated. In addition, Magdalene Laundries were subject to inspection by the statutory regime under the Factories Acts 1907 and 1955 during the period of their operation. According to contemporary records, these inspections of Magdalene Laundries occurred (McAleese, 2013, Chapter I3) but did not address the contemporary prohibition of forced labour in the Irish legal framework at international and national levels during this period, which required payment for this labour. From March I93I, Ireland assumed legal obligations under the I930 Forced Labor Convention to prohibit or suppress forced or compulsory labour. However, even forced or compulsory labour does not presuppose the non-payment of wages. Article I4 of the 1930 Convention requires payment of wages for those undertaking forced or compulsory labour. No historical records indicate whether the Factories Inspectorate ever considered the payment of women and girls working in the laundries (McAleese, 2013, Chapter 5, paras I40-I42; Chapter I2, para. I84). Under the Social Welfare (Employment of Inconsiderable Extent) Regulations 1979, women and girls performing forced labour should have been paid a wage. Nonetheless, the 2013 McAleese Report, discussed below, concluded that the work carried out by the women did not constitute 'insurable employment', as there was no legal obligation to pay the women as no contract of service existed (McAleese, 2013, Chapter I5, paras 105-107).

\subsection{Commonalities}

Several points draw together the two contexts of unpaid labour, not least of all the paternalistic ideals of both regimes. The Australian embezzlement of Indigenous wages appears a more overt form of the denial of economic service and value than in Ireland, where the practices of the state and Church subverted the application of contemporary international standards to exclude the question of payment for forced labour from the national statutory inspection regime and ignored contemporary political awareness of the economic value of the labour. Second, in both contexts, there was a benefit to private industry. The Irish state received an economic benefit from the provision of laundry services to state institutions at below market value, which buttressed the dominant influence of the Church in Irish society and politics. Similarly, in Australia, cheap labour in homesteads and farms provided a form of subsidisation of the private sector that may not have been otherwise economically viable in the fledgling colonies, and even throughout the twentieth century.

Finally, broader social responsibility remains under-emphasised. Of the cases in which routes of entry to Magdalene Laundries are known, only 26.5 per cent were referrals made or facilitated by the state (McAleese, 2013, Introduction, para. 2). Over io per cent of women recorded as detained in Magdalene Laundries were brought there by family members, 8.8 per cent by Roman Catholic priests, 9.3 per cent by other non-state agencies, organisations and individuals, and I6.4 per cent were girls and women who presented themselves, seeking admission (McAleese, 2013, Chapter I8). The laundries enabled Irish society, not merely state institutions, to enforce compliance with a restrictive and religious social morality - and to isolate or deny those who failed to comply with its strictures. In Australia, the assimilationist agenda of placing girls and women in White 
households formed part of a dedicated programme of social design, with women and girls understood by the state, society and the churches as the malleable agents in the Indigenous population that was destined to be refined, if not eliminated.

\section{Responding to a legacy of historical abuse}

\subsection{Stolen-wages campaigns in Australia}

In Australia, civil claims made in the Industrial Relations Commission and the Human Rights Commission finally prompted government action on redress, after over fifty years of agitation. Concerns about the conditions of Indigenous Australians were raised in British and Australian anti-slavery circles from the late nineteenth century (Evans, I984, p. I83). Although Australia did not ratify the 1926 Slavery Convention until I953, it was an early signatory to the I930 Forced Labor Convention. Regardless, it was not until after World War II, related labour shortages and the international focus on colonised peoples that the cause of stolen wages began to be progressed. Wages campaigns corresponded with the maturity of Australian industrial relations and civil rights campaigns, and tended to highlight men's work and their militant unions, thereby obscuring the centrality of women's and children's work to Indigenous economic oppression. After the war, unions that were previously hostile to Indigenous workers came to represent their cases, including supporting the landmark I946 Pilbara strike in WA, which saw at least 800 Aboriginal pastoralists walk off cattle stations for up to three years (Hess, I994, p. 65).

In I965, at the height of campaigns for Indigenous suffrage and constitutional recognition, strike action forced the Industrial Relations Commission (IRC) to finally hear an application for Aboriginal workers to be included in the Cattle Station Industry (Northern Territory Award) I95I and be paid the minimum award wage (which was still less than their White counterparts, who were paid aboveaward wages). Although the IRC ordered that the exclusionary provisions concerning Indigenous workers be removed from the award, it also ruled that Indigenous work was worth less than the award wage due to the 'semi-tribalised' state of Aborigines and their lack of 'skills' (as opposed to their innate abilities) (Anthony, 2007a, pp. I8-2I).

In the era of equality legislation, discrimination suits came to be pursued, particularly in Queensland. Hamstrung by statutes of limitations, the lack of retrospectivity of the Racial Discrimination Act I975 (RDA), and a complete failure to maintain records on the part of pastoralists and government bodies alike, the civil path to redress has been particularly hardfought and resisted by governments that have challenged complainants at 'every step of the way' (Thornton and Luker, 2009, p. 662). In Bligh, the Queensland government was found to have breached the RDA in regard to its discriminatory wage practices for six male workers employed by the state from I975 to I986 (Bligh \& Others $v$. State of Queensland [I996] HREOCA 28). Modest awards of $A \$ 7,000$ belied the value of settlements that were soon to be made with thousands of Indigenous workers who came forward following the decision (Kidd, 2006, p. 9). In Baird, concerning men and women working and living on Church-run reserves (Baird v. State of Queensland [I996] HREOCA 28; (No 2) (2005) I56 FCR 45I), the Queensland government argued that the Lutheran Church, which ran the reserves, was responsible for the underpayment of wages, despite having funded them with grants so minimal as to necessitate the payment of low or no wages to residents. On appeal, claimants were ultimately awarded damages and costs of between $A \$ 17,000$ and $A \$ 85,000$, and an apology (Thornton and Luker, 2009, pp. 666-667).

The threat of future lawsuits prompted Queensland to introduce the Underpayment of Award Wages Process (redress scheme), offering payments of $A \$ 7,000$ to past workers of reserves from the time of the enactment of the RDA, until i986. Workers who had been employed on Church-run missions were not entitled to the scheme, as they were deemed not to have been employed by the 
state (Australian Human Rights Commission, 2006). In 2002, the Queensland government then introduced the Indigenous Wages and Savings Reparation Offer, for the reparation wages controlled under Protection Acts. The second scheme was even more meagre than the first, offering individual payments of between $A \$ 2,000$ and $A \$ 4,000$, depending on claimants' age, rather than their individual losses. Many prospective claimants boycotted the scheme and over A \$36 million remained unclaimed (Thornton and Luker, 2009, pp. 669-670). In 2004, the NSW government followed suit, establishing the Aboriginal Trust Fund Repayment Scheme to repay unpaid wages and other benefits held in trust by the state's Aborigines Protection Board. The NSW scheme is upheld as a better model than Queensland's, due to the consultation with Indigenous people informing its design. However, concerns persist about the likelihood that the NSW scheme will make 'a gross underestimate of money owed to Indigenous people because of the starting point for calculations' (Standing Committee on Legal and Constitutional Affairs, 2006, p. I55), and about its reliance on 'evidence' for elderly, frail and systemically disadvantaged individuals to prove their claims (Thornton and Luker, 2009, p. 67I), especially women, whose capacity to negotiate must be viewed through the lens of gendered power relations.

The enduring outcome of the Queensland lawsuits was to force the commonwealth to address the issue in the 2006 Senate Inquiry into Unfinished Business: Indigenous Stolen Wages. The inquiry was established as an exercise to inquire and report on the details of the financial, policy and legal arrangements governing 'Indigenous workers whose paid labor was controlled by the government' (Standing Committee on Legal and Constitutional Affairs, 2006, p. I). Notably, it did not consider the question of unpaid labour, thereby avoiding any discussion of slavery or indentured labour, and it did not investigate the role of churches and Christian organisations in the underpayment or theft of wages. The inquiry's work was hindered by the lack of co-operation by the WA, Victorian, South Australian, Tasmanian and commonwealth governments, which refused to make submissions. The complex and changing governance of the NT also means that records relating to the jurisdiction with the greatest historical reliance on Indigenous pastoral workers are not available (Anthony, 2007b, p. 4).

While an important juncture in the campaigns for justice, Unfinished Business has had little influence over those recalcitrant governments that continue to resist comprehensive, or any, redress. The NT, where wealth was built on the back of Indigenous cattle workers and their families, has provided no redress at all. In 20I2, WA Indigenous leaders reacted with 'disbelief and disgust' when a one-off payment of A $\$ 2,000$ was offered under the state’s new Stolen Wages Reparation Scheme as compensation for decades of non-payment of wages (Kinnane et al., 20I5, p. 49), after government whistleblowers revealed that the State Treasury had calculated amounts as high as $\mathrm{A} \$ 78,000$ (ABC Radio National, 2015).

In Australia, campaigns have moved between state and federal arenas to pursue both legal and political remedies for redress. The federal structure has allowed multiple points of entry and leverage, but has ultimately resulted in grossly uneven outcomes for complainants residing in different jurisdictions, reflecting the sovereignty of states enshrined in the Australian Constitution. Furthermore, the absence of rights enunciated in the Constitution and a regional human rights mechanism, along with a lack of retrospectivity of equality legislation such as the RDA, has meant that human rights instruments have had only limited effect. While some advocates have attempted to raise the issue in the context of Australia's reporting to the United Nations Human Rights Council and treaty-monitoring bodies, this has gained no traction with the government or the international community, which has instead been preoccupied with other human rights abuses against Indigenous Australians (Australian Human Rights Commission, 2009; Aboriginal Legal Service of Western Australia, 2010). Even more ingenious legal claims have instead been pursued: in late 20I6, a class action was lodged in the Australian Federal Court claiming that the Queensland government had breached its fiduciary duty in regard to Indigenous Australians (Hans 
Pearson v. State of Queensland QUD 7 I4/2016). While this promises to be the most inclusive action yet, for both men and women, it too will apply only to workers of Queensland.

\subsection{Magdalenes' redress}

The campaign for justice for Magdalene women commenced much later than the Australian stolenwages campaigns, illustrating the lack of priority given to female experiences of historical abuse. Ireland previously addressed abuse in industrial schools only in the late twentieth century, which had primarily concerned child sexual abuse, involving both boys and girls (Ryan, 2009). Addressing historical abuse had primarily been a matter of domestic journalistic and victimsurvivor advocacy. Campaigns for redress for Magdalene women represent a key development and distinction from the Australian experience, in the employment of international human rights mechanisms to foster a political shaming of the Irish state through legal mechanisms. However, such campaigns were broadly framed, addressing not only unpaid wages, but also allegations of physical abuse and arbitrary detention.

The initial response of the Irish state to redressing harm in Magdalene Laundries was to deny knowledge regarding what occurred (Irish Times, 20I0). In 20I I, prompted by a submission by the advocacy group Justice for Magdalenes, the United Nations Committee against Torture expressed grave concern at Ireland's failure to protect girls and women who were involuntarily confined between 1922 and I996 in the laundries, by failing to regulate and inspect their operations, where it was alleged that physical, emotional abuses and other ill-treatment were committed, amounting to breaches of the Convention (Committee against Torture, 20II, para. 2I). The committee also recommended that Ireland institute investigations into all allegations of torture and other cruel, inhuman or degrading treatment or punishment, prosecute and punish the perpetrators, and ensure that all victims obtain redress and have an enforceable right to compensation, including the means for as full rehabilitation as possible.

Based on these findings, An Taoiseach Enda Kenny offered an apology in parliament to the women who resided in the Magdalene Laundries. The Taoiseach described the Magdalene Laundries as 'the nation's shame' and accepted the state's direct involvement:

'Therefore, I, as Taoiseach, on behalf of the State, the government and our citizens deeply regret and apologise unreservedly to all those women for the hurt that was done to them, and for any stigma they suffered, as a result of the time they spent in a Magdalene Laundry.' (Kenny, 20II)

This apology, while welcomed by victim-survivor groups, eschewed framing the harm experienced as a question of legal rights and responsibilities. In response, Ireland appointed an Inter-Departmental Committee (IDC) to establish the facts of state involvement with the Magdalene Laundries (McAleese, 2013, Introduction). The McAleese Report presented the testimony of victim-survivors as 'stories', rather than as evidence, and did not issue recommendations regarding accountability, responsibility or criminality (McAleese, 2013, Chapter I9). This is a function of the choice of form of investigation. The alternative use of the Irish Commission of Inquiry Act 2004 would enable testimony of victim-survivors to be recorded as evidence, but not used in civil or criminal proceedings. The McAleese Report minimised the representation of harm in the laundries, drawing favourable comparisons to harm experienced in residential and industrial schools, previously the subject of statutory commissions of inquiry in Ireland (McAleese, 2013, Introduction, p. I8). The committee found that the laundries operated at a subsistent level and could not have existed without state financial support (McAleese, 2013, Chapter 9) and were understood historically to be financially unsustainable if wages were to be paid (McAleese, 20I3, Chapter I2, paras I92, I95). 
In the view of the Irish Human Rights and Equality Commission, the McAleese Report indicates that the laundries fulfilled a function that was otherwise the obligation of the state, as a significantly cheaper alternative to state care (IHREC, 20I3, para. 60), but the commission failed to critique the exclusion of unpaid wages from consideration in the McAleese Report. The laundries can be considered to be a regime that operated in a discriminatory and gendered system of detention entirely for women and girls who shared economic dependence, poverty and social exclusion. Claire McGettrick of the survivor and advocacy group, Justice for Magdalenes, describes the manner in which the committee interviewed survivors of the laundries:

'Initially, the committee didn't even want to speak to women in person, but we fought for that. The women gave their testimony verbally and then we were given very little notice of a second meeting where we were to look at the format of the initial testimony. Instead, the women were brought in one by one for a meeting with the commission where they asked repeated questions. Their overall impression was that they were being checked to ensure that their memories were correct. The women came out of those meetings very quiet and subdued. None of them, none of us, had been expecting for them to be questioned like that.' (McGettrick, 2013)

Mairead Enright critiques the report's findings on physical abuse, suggesting it

'consists of disjointed quotations from anonymised women, selected apparently at random. The women are allowed scant quotations in which to share their stories. This is in contrast to, for instance, the long passages of quotation from identified benign male authority figures later in the chapter.' (Enright, 2013a)

The existence of two oral history projects counters the minimisation of harm and lived experience of survivors in the presentation of the McAleese Report (O'Donnell et al., 20I3; Waterford Memories, 20I3).

Based on the McAleese Report, Mr Justice Quirke was asked to provide a report on the establishment of an ex gratia scheme and related matters for the benefit of those women who were admitted to and worked in the Magdalene Laundries. After consultations with Magdalene women and religious orders, an ex gratia scheme was recommended for the benefit of the women concerned based on the length of their documented service in the laundries as found in the McAleese findings, including access to the full range of state-provided health services (Quirke, 20I3, paras 2.04-2.07). Second, the report took into account 'the harsh and physically demanding work required of the women and the traumatic, ongoing effects which their incarceration and misery within the laundries has had upon their security, confidence and self-esteem' (Quirke, 20I3, para. 2.II) The report concluded that the women were entitled to recognition, through monetary payment, that they worked 'within (and, arguably to an extent for), the State for a period of time' (Quirke, 20I3, para. 2.II).

Elsewhere, the report states, however: 'the payments are not intended to reflect or include a calculation of loss of earnings sustained by the women. The payments are simply intended to express the "sincere nature of the State's reconciliatory intent"' (Quirke, 2013, para. 5.I5). The report concluded that the Magdalene women should be paid a minimum sum of €10,000 up to a maximum of $€ 100,000$, to reflect 'work undertaken' (Quirke, 2013, para. 5.15). Further recommendations included a memorial payment equivalent to the state pension and assistance to Magdalene women. The report noted that the scheme was novel and compared it to similar ex gratia schemes in Australia (Winter, 2009). The report emphasised that such monetary payments cannot and will not fully compensate them for what they have endured, but was intended to address their current needs and reduce the level of injury, pain and hurt that they have suffered 
(Quirke, 20I3, para. 3.I2). In June 2013, the Irish government accepted Judge Quirke's recommendation for an ex gratia lump-sum payment scheme for women affected: the Redress for Women Resident in Certain Institutions Act 2015 also provided the state shall make available health services to participants in the scheme without charge, including general medical practitioners, counselling services and physiotherapy. The Quirke Scheme fundamentally fails to frame the question of state legal responsibility for the harm experienced, including acknowledgement for unpaid wages; nor does it address the broader question of the mistreatment of women while detained in the laundries. In contrast to reformatory and industrial schools, the relevant religious orders have refused to contribute to the compensation fund for victim-survivors. Enright concludes: 'There is a danger that if the state is perceived to have downgraded the Magdalene women's financial entitlement, then the restorative expression of sincerity will begin to look more like risk management' (Enright, 20I3b). Similarly, Stephen Winter suggests that the 'focus on documents decenters the applicant. Personal experience is not the subject of redress ... the focus on documents means that the primary evidence of inclusion is not participatory' (Winter, 20I7, p. I4).

\section{Conclusion: comparing the contexts and campaigns for redress}

This paper has emphasised the common role of gender in the struggle for recognition of labour in each country's history. It is undeniable that, despite the use and abuse of women and children's work in Australia, it was men's work, and particularly iconic masculine work at that, that progressed campaigns for justice in the twentieth century. Men's strike action first gained political traction in campaigns for wages reform and redress; however, due to the regional legal context, campaigns have mostly remained internal to Australia. In contrast, campaigns to provide redress for Irish historical abuse began in earnest in the early I990s, but primarily addressed the sexual abuse of boys in dioceses of the Irish Catholic Church and in residential schools. The gendered dimension of the harm to Magdalene women has resulted in a delayed form of response from the state that was prompted by supranational intervention and shaming through UN human rights mechanisms that have not been effectively pursued in Australia. What both case-studies illustrate is the particular vulnerability of women to socio-economic injustices and orthodox remedies, in terms of what states provide and how transitional justice scholars and practitioners conceptualise redress.

The particular nature of gender-based violations has come to be recognised in international criminal law (Chappell, 20I5) and associated theories of transitional justice applied to postauthoritarian and post-conflict societies (Rubio-Marin and de Greiff, 2007, p. 318). The heightening recognition that 'gender roles, norms and stereotypes can affect the recognition and proper identification' of human rights violations (Urban Walker, 20I5, p. I) has underscored the probability that traditional reparation programmes are unlikely to provide an equal facilitation of the goals of 'recognition, civic trust and social solidarity for men and women' (Rubio-Marin, 2009, p. 3). Attention paid to women's experiences in conflict zones has allowed for the identification of particular opportunities, pitfalls and risks of providing reparations for women, especially in regard to sex-based violations (Urban Walker, 20I5, p. I). For Urban Walker, the 'central challenge' is to ensure that 'the entrenched oppression, marginality and disadvantage does not result in members of disadvantaged groups being deprived of recognition as victims and access to full and effective reparations' (2015, p. 2).

Because the focus, in law, theory and practice, has mainly been on sexual violations we suggest, along with Sankey (2015), that the impact of socio-economic injustices for women has been overlooked or minimised, while the central influence of gender in perpetuating injustice has received even less attention. We argue that the redress provided in both Ireland and Australia 
perpetuates the historic paternalism of colonialism by providing a remedy to relevant men and women out of benevolence and choice, not as a matter of legal right. This paternalism has enduring effects for the citizenship and standing of all victim-survivors, especially women who, in both contexts, typically remain systematically disadvantaged, impoverished and marginalised (Watson, 20II; JFM, 20I5, p. 64).

Australian governments have strongly resisted conceding that they are responsible for unpaid wages, or that working conditions were indentured. The approach of the Irish government has been to avoid engaging the legal rights of women detained in the laundries, even under Ireland's contemporary international obligations, such as the I93 I Forced Labor Convention. Despite these similarities, campaigns for justice have adapted to regional differences. The federal structure in Australia has diversified and disaggregated the advocacy to different levels of government, in contrast to lobbying of central government in Ireland. Efforts at redress in Ireland have benefited from appeal to the UN treaty body mechanisms, whereas, in Australia, which enacted some of the world's first equality legislation, the appeal has primarily been to internal equality mechanisms. However, differences in procedural aspects of the national legal systems have also influenced the pace and nature of redress. The resort to class actions in Australia is not an option under Irish legislation (Blennerhasset, 20I6). In contrast, the recent European Court of Human Rights decision in O'Keeffe v. Ireland ([2014] ECHR 96) held Ireland responsible for a failure to prevent historical child sexual abuse in schools and may provide a basis for challenging state policy on redress for historical abuse in other areas and demonstrate the value of international human rights to the historical redress context (O'Keeffe v. Ireland [2014] ECHR 96).

Both campaigns reflect the post-colonial conception of agency, which refers to the ability of the colonised to engage with or resist colonialism (Ashcroft et al., I998, pp. 8-9). In the Irish context, the refusal of Magdalene women to accept the necessity of the dominant narratives of the past challenged the acceptance of laundries as a necessary part of the state's inherited structures of social control and outsourcing of social welfare. Rather than reflecting the usual post-colonial critique of international law, the Irish experience enables international law to function as a means to challenge national power dynamics to the benefit of a marginalised group of women, albeit in the Global North. In the case of Australia, demands concerning stolen wages as a form of race discrimination challenge colonialist categories of first peoples as peripheral to economic development, and identifies their exploitation as tactical and economic, rather than simply misguidedly paternalistic. In this sense, wages campaigns are integral to post-colonial narratives aiming to correct master-narrative colonial fictions concerning land and resource exploitation. A post-colonial lens demonstrates the risk that a crude application of transitional justice concepts would not challenge the dominant paradigm of liberal democracy that, through its systems and structures, continues to cause harm to Indigenous peoples and would remain non-transformative of their relationship with the state, particularly in socio-economic and property terms (Moyo, 20I2, pp. 265-273).

The post-colonial and gendered approach to these case-studies reveals the potential for continuities between the nature, structures and form of harm experienced by vulnerable and marginalised women in post-conflict states, authoritarian states and, historically but with ongoing consequences, in post-colonial consolidated democracies. The comparisons in this paper suggest the value for transitional justice in learning from a broader set of examples of harm and redress in the consideration of the interaction of gender, harm and redress.

\section{References}

ABC RAdiO National (20I5) 'Background Briefing: WA's Stolen Wages Shame’, 6 September. Available at: 〈http://www.abc.net.au/radionational/programs/backgroundbriefing/wa's-stolen-wages-shame/ 6740068> (accessed 28 October 2017). 
ABORIGINAL LEGAL SERVICE OF WESTERN AUSTRALIA (20I0) 'ATSILS Submission to the United Nations Human Rights Council Universal Periodic Review'. Available at: 〈http://www.als.org.au/ wp-content/uploads/20Io/og/publications_Submissions_ATSILS_Submission_to_UPR_20Io.pdf $\rangle$ (accessed 28 October 20I7).

anthony, T. (2003) 'Postcolonial Feudal Hauntings of Northern Australian Cattle Stations', Law Text Culture 7: 277-307.

Anthony, T. (2007a) 'Reconciliation and Conciliation: The Irreconcilable Dilemma of the I965 "Equal" Wage Case for Aboriginal Station Workers', Labour History 93: I5-34.

anthony, T. (2007b) 'Unmapped Territory: Wage Compensation for Indigenous Cattle Station Workers', Australian Indigenous Law Review I I: 4-29.

AshCroft, B., Griffiths, G. and tiffin, H. (I998) Key Concepts in Post-Colonial Studies. London: Routledge. AUSTRALIAN HUMAN RIGHTS COMMISSION (2006) 'Submission to the Senate Legal and Constitutional

References Committee Inquiry into Stolen Wages', I August. Available at: 〈https://www. humanrights.gov.au/inquiry-stolen-wages> (accessed 28 October 2017).

australian human rights COMmission (2009) 'Review of Australia's Fourth Periodic Report on the Implementation of the International Covenant On Economic, Social and Cultural Rights'. Available at: 〈https:/www.humanrights.gov.au/sites/default/files/content/legal/submissions/ 2009/200904I7_icescr_review.pdf> (accessed 28 October 2017).

BALINT, J., EVANS, J. and MCMillan, N. (2014) 'Rethinking Transitional Justice, Redressing Indigenous Harm: A New Conceptual Approach', International Journal of Transitional Justice 8(2): I94-2I6.

Banks, R. (2008) 'Stolen Wages: Settling the Debt', Australian Indigenous Law Review I 2: 55-67.

bLennerhasset, J. (2016) A Comparative Examination of Multi-Party Actions: The Case of Environmental Mass Harm. Oxford: Hart.

BOUCHER, L. (20I5) 'The I 869 Aborigines Protection Act: Vernacular Ethnography and the Governance of Aboriginal Subjects' in L. Boucher and L. Russell (eds) Settler Colonial Governance in NineteenthCentury Victoria. Acton: ANU Press, 63-94.

CHAPPell, Louise (2015) The Politics of Gender Justice at the International Criminal Court: Legacies and Legitimacy. Oxford: Oxford University Press.

COMMITTEE AGAINST TORTURE (2OI I) 'Consideration of Reports Submitted by States Parties under Article I9 of the Convention: Concluding Observations of the Committee against Torture: Ireland'. CAT/ $\mathrm{C} / \mathrm{IRL} / \mathrm{CO} / \mathrm{I}$.

cunneen, C. (2003) 'Legal and Political Responses to the Stolen Generation: Lessons from Ireland', Indigenous Law Bulletin 5(27): I4-I9.

cunneen, C. (2016) 'When Does Transitional Justice Begin and End? Colonised Peoples, Liberal Democracies and Restorative Justice' in K. Clamp (ed.) Restorative Justice in Transitional Settings. Oxon: Routledge.

CUSSEN REPORT (1936) Report of the Commission of the Inquiry into the Reformatory and Industrial School System I936. Dublin: Stationery Office.

ENRIGHT, M. (2013a) ‘Critiquing the McAleese Report’. Available at: $<$ http://humanrights.ie/economicrights/critiquing-the-mcaleese-report/> (accessed 28 October 2017).

ENRIGHT, M. (2013b) 'What's Wrong with the Magdalenes Redress Scheme?'. Available at: 〈http:// humanrights.ie/gender-sexuality-and-the-law/whats-wrong-with-the-magdalenes-redress-scheme/> (accessed 28 October 2017).

EVAns, R. (I984) "Kings" in Brass Crescents: Defining Aboriginal Labour Patterns in Colonial Queensland' in K. Saunders (ed.) Indentured Labour in the British Empire I834-1920. London: Croom Helm. 
DE GREIFF, P. (2006) 'Introduction: Repairing the Past: Compensation for Victims of Human Rights Violations' in P. de Greiff (ed.) Oxford Handbook of Reparations. Oxford: Oxford University Press, $\mathrm{I}-\mathrm{I} 8$.

Gallen, J. (2016) 'Jesus Wept: The Roman Catholic Church, Child Sexual Abuse and Transitional Justice', International Journal of Transitional Justice I0: 332-349.

garvin, T. (2005) Preventing the Future: Why Was Ireland So Poor for So Long? Dublin: Gill \& McMillan. GRAY, P. (2009) The Making of the Irish Poor Law I8I5-43. Manchester: Manchester University Press. HEss, M. (I994) 'Black and Red: The Pilbara Pastoral Workers' Strike, I 946', Aboriginal History I8(I): 65-83. HUMAN RIGHTS AND EQUAL OPPORTUNITY COMMISSION (I997) Bringing Them Home: Report of the National Inquiry into the Separation of Aboriginal and Torres Strait Islander Children from Their Families. Sydney: Human Rights and Equal Opportunity Commission.

INDEPENDENT INQUIRY INTO CHILD SEXUAL ABUSE (IICSA) (2017) Available at: 〈https://www.iicsa.org.uk〉 (accessed 3I October 2017).

INGLIS, T. (I998) Moral Monopoly: The Rise and Fall of the Catholic Church in Modern Ireland. Dublin: UCD Press, I40, I47-I48.

IRISH HUMAN RIGHTS AND EQUALITY COMMISSION (IHREC) (20I3) Follow Up Report on State Involvement with Magdalene Laundries. Dublin: IHREC.

IRISH HUMAN RIGHTS COMMISSION (IHRC) (20I0) Assessment of the Human Rights Issues Arising in relation to the 'Magdalene Laundries', November. Dublin: IHRC.

IRISH TIMES (20I0) 'State Still in Denial over Magdalene Scandal', I5 June.

JUNG, C. (20II) 'Canada and the Legacy of the Indian Residential Schools: Transitional Justice for Indigenous People in a Nontransitional Society' in P. Arthur (ed.) Identities in Transition: Challenges for Transitional Justice in Divided Societies. Cambridge: Cambridge University Press, 2 I7-250.

JUSTICE For MAGDalenes (JFM) (2OI I) 'Submission to the United Nations Committee against Torture', 46th Session, May. Available at: 〈http://www.magdalenelaundries.com/jfm_comm_on_torture_ 2I04II.pdf> (accessed 28 October 20I7).

JUSTICE FOR MAGDALENES (JFM) (2013) 'State Involvement in the Magdalene Laundries: JFM’s Principal Submissions to the Inter-Departmental Committee to Establish the Facts of State Involvement with the Magdalene Laundries', February 2013. Available at: 〈http://www.magdalenelaundries. com/State_Involvement_in_the_Magdalene_Laundries_public.pdf $\rangle$ (accessed 28 October 2017). JUSTICE FOR MAGDALENES (20I5) 'Death, Institutionalisation \& Duration of Stay: A Critique of Chapter I 6 of the Report of the Inter-Departmental Committee to establish the Facts of State Involvement with the Magdalen Laundries and Related Issues'. Available at: <www.magdalenelaundries. com/JFMR_Critique_I902I5.pdf> (accessed 28 October 2017)

KAPUR, R. (2002) 'The Tragedy of Victimization Rhetoric: Resurrecting the "Native" Subject in International/Post-Colonial Feminist legal Politics', Harvard Human Rights Journal I5: I.

KENNY, E. (2OI I) 'Enda Kenny's State Apology in Full'. Available at: <http://www.thejournal.ie/full-textenda-kenny-magdalene-apology-80 I I32-Feb2013/EndaKenny'sStateApologyinFull > (accessed 28 October 2017).

KIDD, R. (2006) Trustees on Trial: Recovering Stolen Wages. Brisbane: Aboriginal Studies Press.

KILLIAN, S. (20I5) “"For Lack of Accountability”: The Logic of the Price in Ireland's Magdalen Laundries' Accounting, Organizations and Society 43: I7-32.

KINNANE, S., HARRISON, J. and REINECKE, I. (20I5) 'Finger Money: The Black and White of Stolen Wages', Griffith Review 47: 49-70.

LUdDY, Maria (2008) Magdalen Asylums in Ireland, I880-1930: Welfare, Reform, Incarceration? in Armenfürsorge und Wohltätigkeit: Ländliche Gesellschaften in Europa, I850-1930. Frankfurt am Main: Peter Lang, 283-305.

Lundy, P. and MCGovern, M (2008) 'Whose Justice? Rethinking Transitional Justice from the Bottom Up', Journal of Law and Society 35(2): 265-292. 
MCALEESE, M. (2013) Report of the Inter-Departmental Committee to Establish the Facts of State Involvement with the Magdalene Laundries. Dublin: Department of Justice.

MCALINDEN, A. and NAYloR, B. (2OI6) 'Reframing Public Inquiries as "Procedural Justice" for Victims of Institutional Child Abuse: Towards a Hybrid Model of Justice', Sydney Law Review 38(3): 277. MCGETTRICK, C. (2013) 'Interviews Lacked Transparency'. Available at: 〈http://clericalwhispers. blogspot.ie/2013/02/interviews-lacked-transparency-say.html> (accessed 28 October 2017). MCGRATH, A. (1987) Born in the Cattle: Aborigines in Cattle Country. Sydney: Allen and Unwin. mitchell, J. and curthoys, A. (20I0) 'How Different Was Victoria? Aboriginal "Protection" in a Comparative Context', Journal of Australian Studies 34(3): 257-273.

MOSES, A.D. (2008) 'Moving the Genocide Debate beyond the History Wars', Australian Journal of Politics \& History 54(2): 248-270.

Moyo, K. (2012) 'Feminism, Postcolonial Legal Theory and Transitional Justice: A Critique of Current Trends', International Human Rights Law Review I: 237-275.

nagy, R. (2013) 'The Scope and Bounds of Transitional Justice and the Canadian Truth and Reconciliation Commission', International Journal of Transitional Justice 7: 52-73.

o'Donnell, K., PEMbroke, S. and MCGetTrick, C. (2013) Magdalene Institutions: Recording an Oral and Archival History, Government of Ireland Collaborative Research Project. Dublin: Irish Research Council.

o'sullivan, E. and o'donnell, I. (2012) Coercive Confinement in Post-Independence Ireland. Manchester: Manchester University Press.

PRIOR, P. (20I2) Asylums, Mental Health Care and the Irish: 1800-20I0. Dublin: Irish Academic Press. QUIRKE, J. (2013) 'Report of Mr Justice Quirke on the Establishment of an Ex Gratia Scheme and Related

Matters for the Benefit of those Women Who Were Admitted to and Worked in the Magdalen Laundries', May. Dublin: Department of Justice.

RAFTERY, M. and o'sullivan, E. (I999) Suffer the Little Children: The Inside Story of Ireland's Industrial Schools. Dublin: New Island.

Robinson, S. (2003) “We Do Not Want One Who Is Too Old”: Aboriginal Child Domestic Servants in

Late I9th and Early 2oth Century Queensland', Aboriginal History 27: I62-I82.

Robinson, S. (20I4) “"Always a Good Demand”: Aboriginal Child Domestic Servants in Nineteenth- and

Early Twentieth-Century Australia', in V. Haskins and C. Lowrie (eds) Colonization and Domestic

Service: Historical and Contemporary Perspectives. New York and London: Routledge, 97-I I 2.

ROCK, Paul (2002) 'On Becoming a Victim' in Carolyn Hoyle and Richard Wilson (eds) New Visions of

Crime Victims. Oxford: Hart Publishing, I-22.

RUBio-MARIN, Ruth (2009) 'Introduction: A Gender and Reparations Taxonomy' in Ruth Rubio-Marin

(ed.) The Gender of Reparations: Unsettling Sexual Hierarchies while Redressing Human Rights

Violations. Cambridge: Cambridge University Press.

RUBio-MARIN, Ruth and DE GREIFF, Pablo (2007) 'Women and Reparations', International Journal of Transitional Justice (0)I: 318-337.

RYAN, S. (2009) Report of the Commission to Inquire into Child Abuse. Dublin: Official Publications.

SANKey, Diana (2015) 'Gendered Experiences of Subsistence Harms: A Possible Contribution to

Feminist Discourse on Gendered Harms', Social and Legal Studies 24(I): 25-45.

sкöLD, J. (2015) 'Apology Politics Transnational Features' in J. Sköld and S. Swain (eds) Apologies and the

Legacy of Abuse of Children in 'Care'. Basingstoke: Palgrave, I3-26.

SкöLD, J. (2016) 'The Truth about Abuse? A Comparative Approach to Inquiry Narratives on Historical

Institutional Child Abuse', History of Education 45(4): 492-509.

Sмiтн, J. (2007) Ireland's Magdalen Laundries and the Nation's Architecture of Containment. Boston:

University of Notre Dame Press.

STANDING COMMITTEE ON LEGAL AND CONSTITUTIONAL AFFAIRS, PARLIAMENT OF AUSTRALIA (2006) Unfinished

Business: Indigenous Stolen Wages. Canberra: Commonwealth of Australia. 
60 JAMES GALLEN

thornton, M. and Luker, T. (2009) 'The Wages of Sin: Compensation for Indigenous Workers', University of New South Wales Law Journal 32(3): 647-673.

TURNER, C. (2017) Violence Law and the Impossibility of Transitional Justice. London: Routledge.

URBAN WALKER, Margaret (20I5) 'Transformative Reparations? A Critical Look at a Current Trend in

thinking about Gender-Just Reparations', International Journal of Transitional Justice O(I): I-I 8.

WATERFORD MEMORIES (2013) Available at: 〈https://www.waterfordmemories.com/recordings〉 (accessed 3I October 20I7).

WATson, Nicole (20II) 'The Northern Territory Emergency Response - Has It Really Improved the

Lives of Aboriginal Women and Children?', Australian Feminist Law Journal 35: I47-I63.

WHITE, J.M. (20I I) 'Histories of Indigenous-Settler Relations: Reflections on Internal Colonialism and

the Hybrid Economy', Australian Aboriginal Studies I: 8I-96.

WINTER, S. (2009) 'Australia’s Ex Gratia Redress', Australian Indigenous Law Review I3(I): 49.

winTer, S. (20I4) Transitional Justice in Established Democracies: A Political Theory. Basingstoke, UK:

Palgrave MacMillan.

winter, S. (2017) 'Two Models of Monetary Redress: A Structural Analysis', Victims \& Offenders (forthcoming): I-I4.

ZAPPONE, K. (20I7) 'Commission on Mother and Baby Homes: Second Interim Report Published Today;

Health and Well-Being Needs of Survivors and Former Residents to Be Acted on; Improved Access to Information for Those Who Were in Mother and Baby Homes; Expert Appointed to Help Identify Transitional Justice Approach'. Available at: 〈https://www.dcya.gov.ie/viewdoc.asp? DocID=4I79> (accessed 3I October 20I7). 